International Research Journal of Engineering, IT \& Scientific Research
Available online at https://sloap.org/journals/index.php/irjeis/
Vol. 7 No. 3, May 2021, pages: 87-96
ISSN: 2454-2261
https://doi.org/10.21744/irjeis.v7n3.1530

\title{
Comprehensive Assessment and Its Relationship with High School Students Learning
}

\author{
Israel David Carofilis Mendoza a \\ Yenny Rossana Comboza Alcívar ${ }^{b}$ \\ María Virginia Garcés Sabando ${ }^{c}$ \\ Nory Andreina Sornoza Pico ${ }^{d}$
}

Article history:

Submitted: 9 January 2021

Revised: 27 February 2021

Accepted: 18 April 2021

\section{Keywords:}

comprehensive evaluation; learning; performance; skills;

\begin{abstract}
The research aims to analyze comprehensive assessment and its relationship with student learning in a particular educational unit in the city of Portoviejo. The applied methodology has a mixed approach (qualitative and quantitative), an exploratory research was carried out to analyze the problem. The research techniques used were the survey of the teaching staff of the institution and the academic averages of the elementary school students. The results reflected that in the institution the comprehensive evaluation is partially applied, which is reflected in an acceptable academic performance. It was concluded that teachers apply evaluative instruments as they deem necessary, there is no homogeneity between hetero-evaluation, co-evaluation and self-evaluation.
\end{abstract}

International research journal of engineering, IT \& scientific research (C) 2021. This is an open access article under the CC BY-NC-ND license (https://creativecommons.org/licenses/by-nc-nd/4.0/).

\section{Corresponding author:}

Mendoza, I. D. C.

Pontificia Universidad Católica del Ecuador, Portoviejo, Manabí, Ecuador

Email address: icarofilis9669@pucesm.edu.ec

a Pontificia Universidad Católica del Ecuador, Portoviejo, Manabí, Ecuador

b Pontificia Universidad Católica del Ecuador, Portoviejo, Manabí, Ecuador

c Pontificia Universidad Católica del Ecuador, Portoviejo, Manabí, Ecuador

d Pontificia Universidad Católica del Ecuador, Portoviejo, Manabí, Ecuador 


\section{Introduction}

Part of the teaching task is to evaluate students, both in their performance and in their performance. The comprehensive assessment allows detecting learning problems to monitor students, through an improvement plan in the teaching-learning process. This research is of importance since there are educational institutions where precise indicators are not mastered to evaluate the learning of skills, which is sometimes aggravated by the teacher's ignorance of the set of essential skills of a subject, a certain number of teachers do not fully comply with the application of comprehensive evaluations (Wei et al., 2000; De Fraiture et al., 2010). The comprehensive assessment shows what students learn, how they learn it, as well as what the teacher teaches, how he teaches it. The teacher analyzes the student to find a way to develop knowledge to the maximum (Zambrano, 2016).

Assessment actions and practices have repercussions, not only on the student's academic performance and promotion, but also on other aspects of integral development, such as their personality and self-esteem. The image that students build of themselves can be influenced by the personal experience of the evaluation that they have undergone, which will be part of their professional future (Villarroel, 2012). Improving assessment methods is a topic that teachers are constantly looking for. An investigation carried out in Ecuador reflected that teachers must value students for their merits during the evaluation process, which must be permanent and adapted to the student (Navarro, Falconí, \& Espinoza, 2017).

Through evaluation processes, students develop values and form criteria to face reality and respond to it; through the integral and formative evaluation processes, the classification that distinguishes an evaluation focused on differences and on the regulation of learning can be determined. It requires a high level of application on the part of the teacher, bringing with him the objective to be achieved in the teaching-learning process, this dynamic involves all actors in education.

\section{Materials and Methods}

The present study was based on a mixed approach (qualitative-quantitative) (Johnson \& Onwuegbuzie, 2004) define the mixed approach as a study where the researcher uses qualitative and quantitative research techniques, methods, and approaches in the same study. The type of research was exploratory, which allowed us to analyze the problem that was not clearly defined. The research scenario was located in an educational unit in the city of Portoviejo, the population was the 23 teachers of the institution and the 155 students of elementary school took their grades to demonstrate academic performance. The research methods were analytical and synthetic, which made it easier to contrast theory with practice. Surveys were applied to the 23 teachers who work in the institution. Scores were tabulated based on school performance.

\section{Results and Discussions}

To promote the integral evaluation so that it is applied in its entirety, the co-evaluation, self-evaluation and heteroevaluation must be taken into account. to obtain a broader understanding of the contents, training individuals who are competent to cope and face situations that arise in their daily lives.

\section{Evaluation}

The term evaluate comes from the French word évaluer, which means "to determine the value of something." Table 1 shows the concepts seen by various authors.

Table 1

Assessment of different authors on the evaluation

\begin{tabular}{|l|l|}
\hline Author & Concept \\
\hline (Rosales, 1990). & $\begin{array}{l}\text { Critical analysis of the instruments, variables and situations that participate in the } \\
\text { didactic process, in order to determine the results of the teaching-learning process }\end{array}$ \\
\hline
\end{tabular}




\begin{tabular}{|l|l|}
\hline & of the students \\
\hline (Mora, 2004) & $\begin{array}{l}\text { Instrument for accountability, it is not based exclusively on evidencing pertinent } \\
\text { information from a study plan, but also on accepting and applying feedback for } \\
\text { personal improvement and achievement of student teachers }\end{array}$ \\
\hline (Pérez, 2015) & $\begin{array}{l}\text { Assessment that through contributions and specific references; of the technical } \\
\text { planned information, ordered, compiled and systematized, based on important } \\
\text { factors that make up the educational processes; to contribute to decision-making } \\
\text { in order to improve teaching }\end{array}$ \\
\hline (Sánchez, 2018) & $\begin{array}{l}\text { Acquisition of information from various sources such as tests, class work, } \\
\text { homework, and various interactions with students. With the aim of defining how } \\
\text { much students have learned, understood and reflected on a particular topic }\end{array}$ \\
\hline (Galbán \& Ortega, 2018) & $\begin{array}{l}\text { Permanent sacrifice that integrates the results of the teaching-learning process, } \\
\text { according to the context that is carried out, to obtain the established purposes }\end{array}$ \\
\hline
\end{tabular}

From these definitions, the concept of evaluation is understood as a process that, through already established criteria, information is obtained that will allow to show the results and if it is possible to make timely decisions to improve the learning process.

\section{Authentic}

evaluation Authentic evaluation establishes improving learning through instruments, techniques, precise procedures that really demonstrate class activities and the appropriate use of didactic resources with the purpose that the alternative evaluation activates the student, systematizing learning for practice daily and is applied throughout life (Ahumada, 2005).

It conceives education and learning in a continuous, holistic and global way, it has a teaching vision in which the activities to be evaluated are at the same time learning activities, they keep continuity and depth with the activities that are carried out in the classroom of classes with which students learn, can be carried out in their professional and daily life (Cárdenas \& Zapata, 2013; Yan et al., 2013; Krausmann et al., 2008). This evaluation makes the student participate, the permanent dialogue between the teacher and the student is important, in which clear ideas are given to know the capacities they have, as well as the activities which must be known by them to be more realistic, this makes it possible to determine what the student is learning and how his performance is, allowing him to make value judgments which will serve for his development in daily life.

\section{The integral evaluation}

The evaluation of the integrality of the students is the planned, permanent process of evaluation and self-evaluation carried out by the actors, it is a cognitive, communicative and evaluative process through the exchange of contents to provide criteria of integral value in order to education (Tamayo, 2018). It must provide what the student does not have, achieve changes in the teaching process with the acquisition of knowledge individually, with the necessary psychological help and inform about the potential of the student's development (González, 2000).

Within the teaching process, various opportunities that contribute to the purpose of learning can be visualized, evaluation is a tool to clarify objectives, confer meanings and guide students in search of the proposed goals (González, 2000; Pope et al., 2006; Ülger et al., 2010). This evaluation involves three main forms: self-evaluation, co-evaluation and hetero-evaluation that includes student participation as an active process of interaction (Fernández $\&$ Vanga, 2015). The three types of evaluation that are applied in the classroom are shown in Figure 1.

Mendoza, I. D. C., Alcívar, Y. R. C., Sabando, M. V. G., \& Pico, N. A. S. (2021). Comprehensive assessment and its relationship with high school students learning. International Research Journal of Engineering, IT \& Scientific 


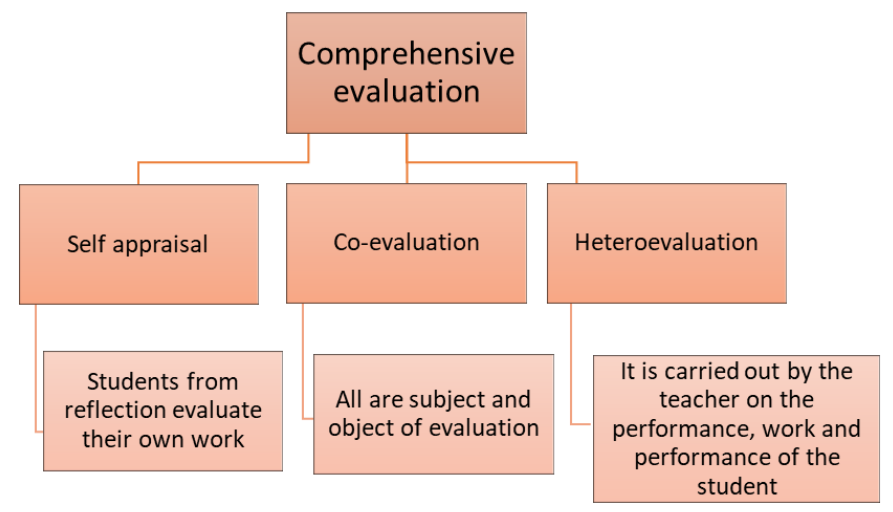

Figure 1. Types of evaluation

Source: (Fernández \& Vanga, 2015)

The self-evaluation and hetero-evaluation of the pedagogical process of the topics taught allow us to know how they are developing the teaching-learning process, as well as the perspective of the teacher and student, guided in the domain of specific objectives of the didactic elements, which are deepened through investigative work (Jara, Aldas, Ávila, \& Bravo, 2020). The heteroevaluation aims at constant improvement, it has evaluative items according to the professional function. The methods are applied between: teacher-student and institution-teacher, to obtain a good performance (Baldeón \& Pabón, 2018).

The self-assessment aims to strengthen one's own ability by providing a better reflective response for each of the actors, it is focused on transforming the quality of education, changing threats into opportunities and individually perfecting the development of the educational establishment (Baldeón \& Pabón, 2018). Co-evaluation and evaluation make it possible to determine individual and group objectives; encouraging participation, the analysis of actions, suggesting solutions, facilitating the development of an integral attitude with responsibility and teamwork (Tamayo, 2018). These types of evaluation are essential within the classroom, allowing the comprehensive evaluation to be applied in an optimized way, seeking to achieve the proposed goals from the external part with the social assessment that the student receives and the internal from the reflection itself composed of the self-assessment.

\section{Formative evaluation}

The evaluation aims to improve the teaching-learning process, guiding students about their academic performance and the achievements to be achieved. The teacher as a guide helps in this procedure, motivating them to develop autonomously (Fernández, 2017). It is one of the methods, which contributes to maintaining motivation, the desire to learn, self-esteem and the ability to accept challenges. This medium allows progress towards the achievement of objectives, within the teaching-learning process (Fernández, 2017). It is potentiated in the analysis of information collected by the teacher, allows to express criteria and incorporate actions to improve student learning (Talanquer, 2015).

This evaluation proposes improvements in three ways: first, it transforms the learning process in students; second, it guarantees progress as competent teachers' day by day; third, it strengthens the teaching-learning processes that are developed in the classrooms with the students (López-Pastor, Sonvella, \& Martínez, 2019).

Formative evaluation is an integral part of teaching-learning, the performance of students is evidenced in various scenarios, who are main actors in the advancement of their achievements; the teacher as a guide, perfects his teaching practice, which benefits the student in his education by encouraging him to learn more.

\section{Assessment instruments}

It is all the material used that allows information to be stored to evaluate the student's academic performance, in an orderly and precise manner, so that it is effective (Hamodi, Lopez, \& Ana, 2015). The evaluation instruments are organized resources raised for specific achievements, adapted to the needs of each student with the required information, the use of any of these is important and give the opportunity to achieve the desired purpose, the teacher must be selective when using these instruments (Ruiz, Rodríguez, Gallegos, \& Villacis, 2018). 
These instruments allow information to be obtained, the teacher relies on them to evaluate the student, at the time of collecting data, this can be systematized in a certain time without becoming contradictory in the assessments, evaluating skills and knowledge; help to promote self-regulation of learning, which allows the student to check if he is competent in what he is learning (García-Garro, Ramos-Ortega, León Ponce, \& Olvera-Chávez, 2007).

Figure 2 shows the different assessment instruments to strengthen students' skills.

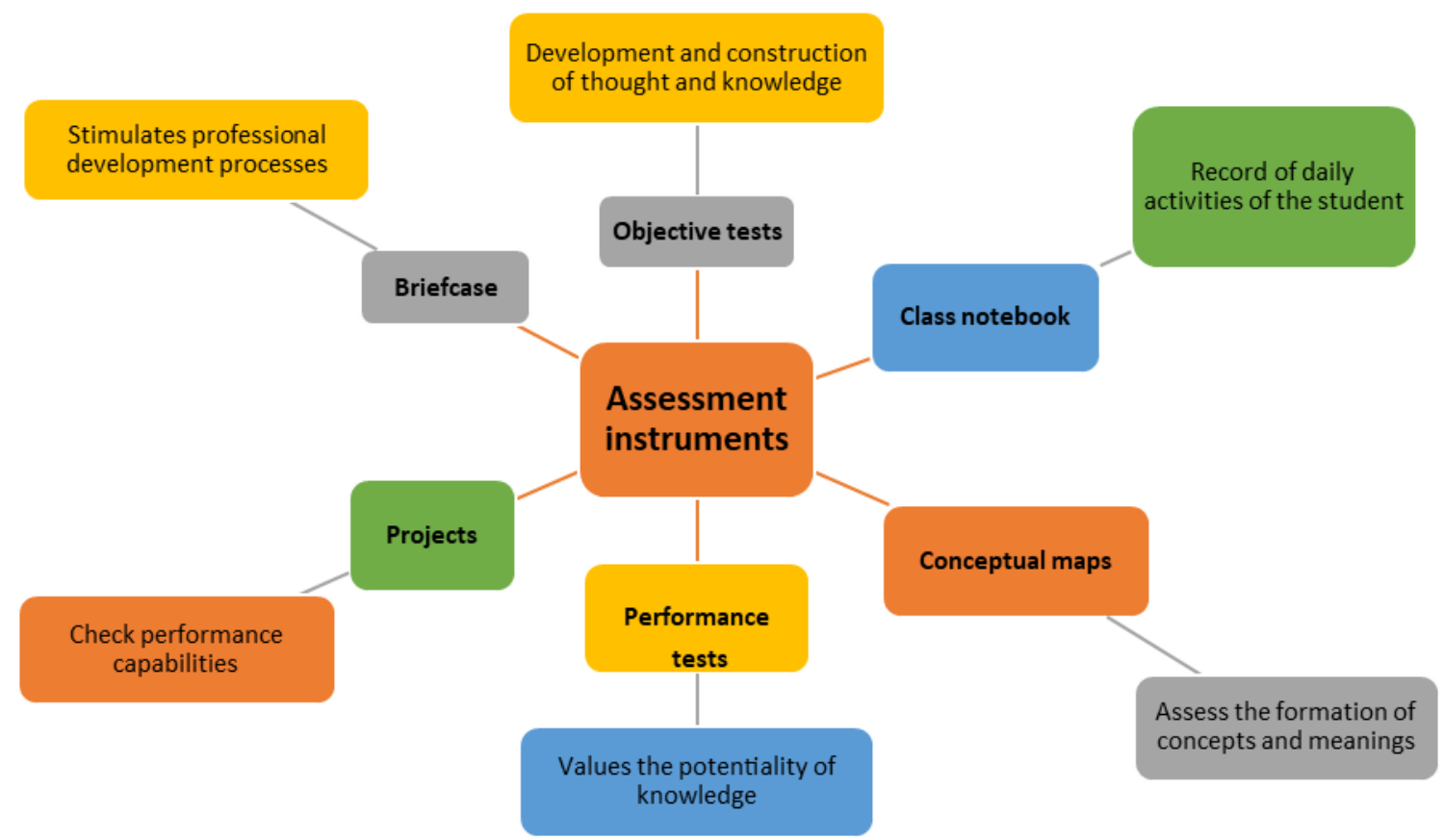

Figure 2. Assessment instruments

Source: (Tejada J., 2011).

- Class notebook: The development of activities, daily progress, reflects ideas, thoughts; the teacher monitors the student's work to provide feedback on the content, generating reflection and guidance in improving processes.

- Objective tests: Set of brief statement items, with several alternatives, existing a valid solution for all students, develops selective thinking more than mental processes, aimed at the construction of knowledge.

- Concept maps: Instrument to evaluate the formation of concepts and meanings, strengthens the depth of knowledge achieved in learning.

- Performance tests: Activities carried out during the training period (carrying out projects, case studies, etc.) to evaluate the achievement of the objectives, assessing the potential of the knowledge.

- Projects: This comprehensive practice contributes to learning by allowing performance capabilities to be verified.

- Portfolios: Premeditated and authorized compilation of the work carried out, where educational progress is evidenced in a given time, stimulates professional development processes.

The assessment tools promote a change significant in the student and the educator, where the participation of the students allows the development of critical, reflective and transformative thinking.

\section{Performance vs Performance}

When talking about academic performance, it is inevitable to relate it to a grade; it is the quantitative reflection of the level of knowledge that the student has acquired and demonstrated in a subject (Jimenez, 1995). Academic performance is supported by performance, it does not refer to a grade. It is the result of all the processes that have affected the student: individual capacities (aptitudes), family life (relationship) and their school reality (qualifications) (Morales, 2007). With these definitions, the purpose of performance is based on a qualification

Mendoza, I. D. C., Alcívar, Y. R. C., Sabando, M. V. G., \& Pico, N. A. S. (2021). Comprehensive assessment and its relationship with high school students learning. International Research Journal of Engineering, IT \& Scientific 
(quantitative) that of performance is related to the evaluation of the student considering the skills, virtues and knowledge acquired applied in daily life (qualitative).

\section{Meaningful learning}

It is a congruent process, without arbitrariness, which leads to the relationship of new information with the previous knowledge found in the student's cognition, existing an interrelation that enriches and expands the discernment of new knowledge (Latorre, 2017). The assessment of significant learning is based on obtaining the resources that seek to store their information, which must be related to the objective to be achieved (Salazar, 2018). The teacher must find a way for the student to have faculty and independence in their own learning, stimulating them in their own situations within the scenario of each one of them.

Ausubel indicates that the student is an active subject of the information process, stating that learning is sequential and orderly, being a complex phenomenon that does not diminish for memory purposes, pointing out the relevance of learning by constructivism in the classroom (Díaz \& Hernández, 2015). Critical thinking is made up of cognitive skills, it needs the student to manage metacognition processes, fundamental in the application of methodologies to achieve meaningful learning, where the student learns while thinking (Chrobak, 2017). Meaningful learning occurs when new information is interactively related to previous knowledge; it implies that the existing ideas or concepts in the learner's cognitive structure are clear and suitable, generating the acquisition of new knowledge, providing an education focused on the training of the student.

To determine how the implementation of the comprehensive evaluation affects academic performance, 23 teachers from a particular educational unit of the city of Portoviejo were surveyed and the quimester grades of the 155 students that make up basic average were averaged. From the results obtained, the information from the survey applied to the teaching staff of the educational unit is presented. Table 2 shows the implementation of heteroevaluation, coevolution and self-evaluation in the evaluation processes.

Table 2

Implementation of evaluation of a group of selected teachers

\begin{tabular}{ccc}
\hline Alternatives & Frequency & $\begin{array}{c}\text { Percentage }(\%) \text { of } \\
\text { participation }\end{array}$ \\
\hline Hetero-evaluation & 18 & 78 \\
Co-evaluation & 18 & 78 \\
Self-appraisal & 6 & 26 \\
\hline
\end{tabular}

Table 2 shows the types of evaluation that teachers use in the classroom, where $78 \%$ use hetero-evaluation and coevaluation. $26 \%$ of the staff use self-evaluation, this being the one with the least presence for the development of student learning. Teachers consider that self-evaluation does not have the same importance as hetero and coevaluation. If this type of evaluation is not applied, learning will become monotonous, preventing students from knowing themselves and reflecting on the knowledge they have acquired (Martínez, Yániz, \& Villardón, 2018). 


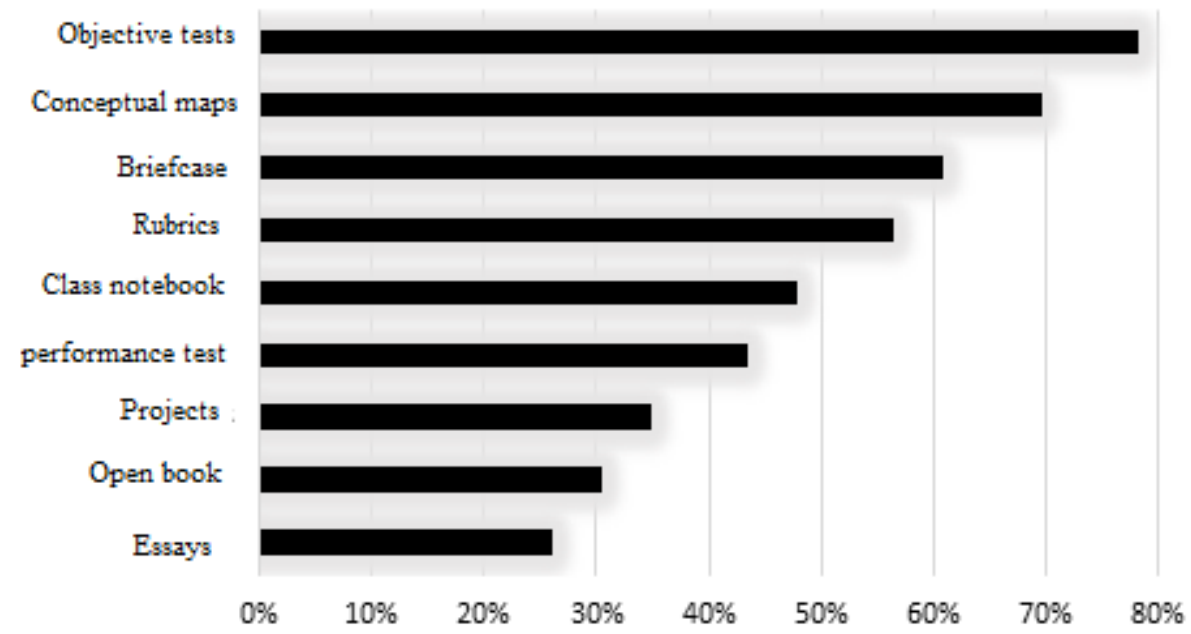

Figure 3. Assessment instruments

Figure 3 shows the trends on the most widely used assessment instruments. $78.3 \%$ of teachers use objective tests, $69.6 \%$ concept maps, $60.9 \%$ portfolios, $56.5 \%$ rubrics, $47.8 \%$ class notebooks, 43 , 5\% performance tests, $34.8 \%$ projects, $30.4 \%$ open book and $26.1 \%$ essays. Teachers apply various instruments within the teaching-learning process to comprehensively evaluate students. Students consider that taking objective tests does not allow them to demonstrate the learning they have obtained; they generate doubt and anxiety. Assessment instruments such as essays and concept maps make them feel motivated, safe and confident (Zuñiga \& Cárdenas, 2014).

Data were taken from the academic averages of the 155 students that make up basic average. Table 3 shows the averages.

Table 3

Average of a group of selected students

\begin{tabular}{ccc}
\hline Alternatives & Frequency & Percentage $(\%)$ \\
\hline Between 9 to 10 & 80 & 52 \\
Between 7 to 8.99 & 70 & 45 \\
Less than 6.99 & 5 & 3 \\
\hline
\end{tabular}

Table 3 shows the averages of the elementary school students of a particular educational unit, where $52 \%$ obtained between 9 to 10 points on average, $45 \%$ obtained between 7 to 8.99 and $3 \%$ obtained a lower average. to 6.99 . The ratings are mostly high with a small portion that is underperforming. The results obtained in the surveys show that teachers apply comprehensive evaluation in a disproportionate way. That is, they prioritize certain types of evaluation over others, such as hetero-evaluation and co-evaluation versus self-evaluation.

This indicates that the students of a particular educational unit are not encouraged to self-analyze, criticize and evaluate themselves, they do not question what they have learned, limiting themselves to being questioned by an external agent to strengthen the teaching and learning process. The teacher listens to his students for the most part, this is thanks to the fact that the feedback is constant, which makes the teacher-student relationship stronger.

Objective, qualitative and mixed assessments, together with the various instruments they use for learning, allow students to develop different skills and abilities. By having this variety, it is stimulated to relate and strengthen everything learned.

\footnotetext{
Mendoza, I. D. C., Alcívar, Y. R. C., Sabando, M. V. G., \& Pico, N. A. S. (2021). Comprehensive assessment and its relationship with high school students learning. International Research Journal of Engineering, IT \& Scientific Research, 7(3), 87-96. https://doi.org/10.21744/irjeis.v7n3.1530
} 


\section{Conclusion}

By strengthening students' knowledge with various assessment instruments, they achieve significant learning, developing various skills. The teacher has the power to choose the one he considers convenient, having a preference for objective tests and concept maps. The academic performance of middle school students is acceptable, but it can improve if a comprehensive evaluation is applied, where hetero-evaluation and co-evaluation do not present a greater preference over self-evaluation.

\section{Conflict of interest statement}

The author(s) declared that they have no competing interest.

\section{Statement of authorship}

The author(s) have a responsibility for the conception and design of the study. The author(s) have approved the final article.

\section{Acknowledgments}

We are grateful to two anonymous reviewers for their valuable comments on the earlier version of this paper. 


\section{References}

Ahumada, P. (2005). Authentic evaluation: a system for obtaining evidence. Educational Perspective, Teacher Training, 45, 11-24. Retrieved from https://www.redalyc.org/pdf/3333/333329100002.pdf

Baldeón, P., \& Pabón, J. (2018). Module of hetero-evaluation and self-evaluation of the professor, based on the SIGE of the Technological University, through the Extreme Programming methodology. (Bachelor's thesis). University of Israel, Quito, Ecuador. Obtained from http://repositorio.uisrael.edu.ec/handle/47000/1671

Cárdenas, F., \& Zapata, P. (2013). Active learning and authentic assessment. Science education: journal of research and didactic experiences(0), 649-654. Obtained from https://dialnet.unirioja.es/servlet/articulo?codigo $=6872807 \&$ orden $=0 \&$ info $=$ link

Chrobak, R. (2017). Meaningful learning to encourage critical thinking. Archives of Educational Sciences, 11(12). Retrieved February 20, 2021, from http://www.memoria.fahce.unlp.edu.ar/library?a=d\&c=arti\&d=Jpr8292

De Fraiture, C., Molden, D., \& Wichelns, D. (2010). Investing in water for food, ecosystems, and livelihoods: An overview of the comprehensive assessment of water management in agriculture. Agricultural Water Management, 97(4), 495-501. https://doi.org/10.1016/j.agwat.2009.08.015

Díaz, A., \& Hernández, R. (2015). Constructivism and meaningful learning. Retrieved February 20, 2021, from http://metabase.uaem.mx/handle/123456789/647

Fernández, A., \& Vanga, M. (2015). Process of self-evaluation, co-evaluation and hetero-evaluation to characterize student behavior and improve their performance. Revista San Gregorio, 6-15. Obtained from http://revista.sangregorio.edu.ec/index.php/REVISTASANGREGORIO/article/view/52

Fernández, S. (2017). Evaluation and learning. MarcoELE. Journal of Spanish Foreign Language Didactics(24). Retrieved February 19, 2021, from https://www.redalyc.org/pdf/921/92153187003.pdf

Galbán, S., \& Ortega, C. (2018). Didactic evaluation of educational software. Pan American Journal of Pedagogy(25). Retrieved February 20, 2021, from https://revistas.up.edu.mx/RPP/article/view/1691

García-Garro, A., Ramos-Ortega, G., León Ponce, A., \& Olvera - Chávez, A. (2007). Evaluation instruments. Mexican Journal of Anesthesiology, 30(3), 158-164. Obtained from https://www.medigraphic.com/pdfs/rma/cma2007/cma073f.pdf

González, M. (2000). Assessment of learning in university teaching. University pedogy magazine, 5(2), 1-26. Obtained from https://profesorailianartiles.files.wordpress.com/2013/04/evaluacic3b3n-del-aprendizaje-enensec3b1anza-universitaria-parte-1.pdf

Hamodi, C., Lopez, V., \& Ana, L. (2015). Means, techniques and instruments of formative and shared evaluation of learning in higher education. Educational Profiles, 37(147), 146-161.

Jara, D., Aldas, H., Ávila, C., \& Bravo, W. (2020). Self-evaluation and hetero-evaluation of the didactic process of the physical education class. Knowledge Pole: Scientific - Professional Journal, 5(11), 350-367. Obtained from https://dialnet.unirioja.es/descarga/articulo/7659477.pdf

Jimenez, M. (1995). Social competence: preventive intervention at school. Childhood and Learning. Obtained from https://www.researchgate.net/profile/Manuel_Jimenez3/publication/259442484_Competencia_social_intervencio n_preventiva_en_la_escuela/links/54461db60cf2d62c304da000/Competencia-social-intervencion-preventiva-enladf (

Johnson, B. 2004). Mixed Methods Research: A Research Paradigm Whose Time Has Come. Educational Researcher, 33(7), 14-26. Retrieved from https://journals.sagepub.com/doi/abs/10.3102/0013189x033007014

Krausmann, F., Erb, K. H., Gingrich, S., Lauk, C., \& Haberl, H. (2008). Global patterns of socioeconomic biomass flows in the year 2000: A comprehensive assessment of supply, consumption and constraints. Ecological Economics, 65(3), 471-487. https://doi.org/10.1016/j.ecolecon.2007.07.012

Latorre, M. (2017). Meaningful and functional learning. Marcelino Champagnat University, 1-11.

López-Pastor, V., Sonvella, M., \& Martínez, S. (2019). Formative and Shared Evaluation in Education. IberoAmerican Journal of Educational Evaluation, 12(1), 5-9. Retrieved from https://www.google.com/url?sa=t\&rct=j\&q=\&esrc=s\&source=web\&cd=\&cad=rja\&uact=8\&ved=2ahUKEwixgo GugPnuAhUSSjABHZaIDB0QFjAGegQIAxAD\&url=https\%3Aartirio=https\%3Aartirio=https\%3Aartirio=https \%3Aartirio=https\%3Aartirio2. 2F6908767.pdf \& usg = AOvVaw0vwkcLlvxyLFSq7RXNv4-6

Martínez, M., Yániz, C., \& Villardón, L. (2018). Teacher self-evaluation and reflection to improve the professional competence of teachers in the knowledge society. NET. Journal of Distance Education, 56(10), 1-30. Obtained from https://www.um.es/ead/red/56/martinez_et_al.pdf

Mora, A. (2004). Educational evaluation: Concept, periods and models. Research News in Education, 4(2), 1-28. Retrieved from https://www.redalyc.org/pdf/447/44740211.pdf

Mendoza, I. D. C., Alcívar, Y. R. C., Sabando, M. V. G., \& Pico, N. A. S. (2021). Comprehensive assessment and its relationship with high school students learning. International Research Journal of Engineering, IT \& Scientific

Research, 7(3), 87-96. https://doi.org/10.21744/irjeis.v7n3.1530 
Morales, F. (2007). The effect of impulsivity on aggressiveness and its consequences on adolescent performance. (Doctoral Thesis). University of Rovira i Virgili, Tarragona, Spain. Retrieved from https://www.google.com/url?sa=t\&rct=j\&q=\&esrc=s\&source=web\&cd=\&ved=2ahUKEwjT8rCLhfnuAhXgSTA BHUTdDR4QFjAAegQIAhAD\&url=https\%3A\%2F\%2Fwww.tdx.cat\%2Fhandle\%2F10803\%2F8962\&usg=AO vVaw2oCBiyzYxqdAGvMqOvPivy

Navarro , N., Falconí, A., \& Espinoza, J. (2017). the improvement of the evaluation process for students in basic education. University and Society, 9(4), 58-69. Obtained from http://scielo.sld.cu/scielo.php?script=sci_isoref\&pid=S2218-36202017000400008\&lng=es\&tlng=es

Pérez, R. (2015). The evaluation of educational programs: basic concepts, general approaches and problems. Journal of Educational Research, 18(2), 261-287. Retrieved February 20, 2021, from https://digitum.um.es/digitum/handle/10201/45401

Pope, D., Ramesh, H., Gennari, R., Corsini, G., Maffezzini, M., Hoekstra, H. J., ... \& Audisio, R. A. (2006). Preoperative assessment of cancer in the elderly (PACE): a comprehensive assessment of underlying characteristics of elderly cancer patients prior to elective surgery. Surgical oncology, 15(4), 189-197. https://doi.org/10.1016/j.suronc.2007.04.009

Rosales, C. (1990). Assess is to reflect on teaching. Narcea.

Ruiz, T., Rodríguez, N., Gallegos, L., \& Villacis, J. (2018). Objective tests as instruments for measuring learning results. Atlante: Notebooks on Education and Development(96), 1-24.

Salazar, J. (2018). Assessment of meaningful learning and learning styles: Scope, proposal and challenges in the classroom. Pedagogical Trends(31), 1-16.

Sánchez, M. (2018). Assessing Student Learning: Is It Really That Complicated? University Digital Magazine, 19(6). Obtained from http://www.revista.unam.mx/2018v19n6/evaluacion-del-aprendizaje-de-los-estudiantes/

Talanquer, V. (2015). The importance of formative evaluation. Chemical Education, 26(3), 177-179. Retrieved February 19, 2021, from http://www.scielo.org.mx/pdf/eq/v26n3/0187-893X-eq-26-03-00177.pdf

Tamayo, R. (2018). Hetero-evaluation, self-evaluation, co-evaluation and shared evaluation: conceptual considerations. Atlante Notebooks on Education and Development. Retrieved from https://www.eumed.net/rev/atlante/2018/10/heteroevaluacion-autoevaluacion.html

Tejada, J. (2011). The evaluation of competences in non-formal contexts, evaluation devices and instruments. Education Magazine(354), 341-342. Obtained from https://dialnet.unirioja.es/servlet/articulo?codigo=3418213\&orden=0\&info=link

Tejada, J. (2011). The evaluation of competences in non-formal contexts: evaluation devices and instruments. Education Magazine, 731-745. Obtained from http://www.revistaeducacion.educacion.es/re354/re354_29.pdf

Ülger, Z., Halil, M., Kalan, I., Yavuz, B. B., Cankurtaran, M., Güngör, E., \& Arıŏul, S. (2010). Comprehensive assessment of malnutrition risk and related factors in a large group of community-dwelling older adults. Clinical Nutrition, 29(4), 507-511. https://doi.org/10.1016/j.clnu.2010.01.006

Villarroel, J. (2012). Qualifications as an obstacle to the development of thought. Sophia, Collection of Philosophy of Education(12), 141-151. Retrieved from https://www.redalyc.org/pdf/4418/441846101009.pdf

Wei, J. T., Dunn, R. L., Litwin, M. S., Sandler, H. M., \& Sanda, M. G. (2000). Development and validation of the expanded prostate cancer index composite (EPIC) for comprehensive assessment of health-related quality of life in men with prostate cancer. Urology, 56(6), 899-905. https://doi.org/10.1016/S0090-4295(00)00858-X

Yan, C. G., Cheung, B., Kelly, C., Colcombe, S., Craddock, R. C., Di Martino, A., ... \& Milham, M. P. (2013). A comprehensive assessment of regional variation in the impact of head micromovements on functional connectomics. Neuroimage, 76, 183-201. https://doi.org/10.1016/j.neuroimage.2013.03.004

Zambrano, L. (2016). Evaluation of the learning of the English language in students of the ninth year of basic education in the parallels "A and B" of the educational unit "Augusto Solórzano Hoyos" canton Chone, Manabí, period 2016. Central University of Ecuador, Chone, Ecuador. Obtained from http://www.dspace.uce.edu.ec/bitstream/25000/11661/1/T-UCE-0010-114.pdf

Zuñiga, C., \& Cárdenas, P. (2014). Assessment instruments: What do students think when they finish compulsory schooling? Educational Perspective. Teacher Training, 53(1), 57-72. Obtained from file: /// C: /Users/ingca/Downloads/Dialnet-InstrumentosDeEvaluacionQuePiensanLosEstudiantesAl-4776618.pdf 